\title{
Affinity Based Nano-Magnetic Particles for Purification of Recombinant Proteins in Form of Inclusion Body
}

\author{
Masoud Seyedinkhorasani ${ }^{1}$, Reza Ahangari Cohan ${ }^{1}$, Saeid Taghavi Fardood ${ }^{2}$, \\ Farzin Roohvand ${ }^{3}$, Dariush Norouzian ${ }^{1^{*}}$ and Malihe Keramati ${ }^{{ }^{*}}$ \\ ${ }^{1}$ Nano-Biotechnology Department, Pasteur Institute of Iran, Tehran, Iran; ${ }^{2}$ Department of Chemistry, \\ University of Zanjan, Zanjan, Iran; ${ }^{3}$ Virology Department, Pasteur Institute of Iran, Tehran, Iran
}

Received 23 February 2019; accepted 4 December 2019; published online 7 December 2019

\begin{abstract}
Background: Protein purification is the most complicated issue in the downstream processes of recombinant protein production; therefore, improved selective purification methods are important. Affinity-based protein purification method using His-tag and Ni-NTA resins is one of the most common strategies. MNPs can be used as a beneficial alternative for Ni-NTA resins. However, there is no data on the capability of MNPs for protein purification from inclusion bodies; this issue is studied here. Methods: Recombinant His-tagged proteins of EGFPHis and SK-His were expressed in E. coli BL-21 (DE3) in soluble and inclusion body forms, respectively. MNPs including $\mathrm{Fe}_{3} \mathrm{O}_{4}$ magnetic core, $\mathrm{SiO}_{2}$ shell, and $\mathrm{Ni}^{2+}$ on the surface were synthesized by sol-gel and hydrothermal reactions and then characterized by XRD, VSM, and SEM imaging. Both synthesized $\mathrm{Fe}_{3} \mathrm{O}_{4} @ \mathrm{NiSiO}_{3}$ and $\mathrm{Fe}_{3} \mathrm{O}_{4} @ \mathrm{Ni}_{\mathrm{x}} \mathrm{SiO}_{\mathrm{y}} \mathrm{MNPs}$ were employed to purify EGEP-His and SK-His under native and denaturing conditions, respectively. The quantity and purity of purified proteins were analyzed by micro-Bradford assay and SDS-PAGE, respectively. Results: Both synthesized MNPs were spherical and well-dispersed with the size ranging from 290 to $415 \mathrm{~nm}$. Synthesized MNPs contained $\mathrm{Fe}_{3} \mathrm{O}_{4}, \mathrm{SiO}_{2}$ shell, and $\mathrm{Ni}^{2+}$ on their structures with suitable magnetization properties. Using $\mathrm{Fe}_{3} \mathrm{O}_{4} @ \mathrm{NiSiO}_{3}$ and $\mathrm{Fe}_{3} \mathrm{O}_{4} @ \mathrm{Ni}_{x} \mathrm{SiO}_{\mathrm{y}}$ yielded 192 and $188 \mu \mathrm{g} / \mathrm{mg}$ of SK-His, as compared to 207 and $195 \mu \mathrm{g} / \mathrm{mg}$ of EGFP-His, respectively. Conclusion: MNPs containing magnetic $\mathrm{Fe}_{3} \mathrm{O}_{4}$ core, $\mathrm{SiO}_{2}$ shell, and $\mathrm{Ni}^{2+}$ on their surface are versatile alternatives for Ni-NTA resins in protein purification for proteins expressed in both soluble and inclusion body forms. DOI: 10.29252/ibj.24.3.192
\end{abstract}

Keywords: Inclusion body, His-tag, Magnetic nanoparticle, Protein purification

Corresponding Authors:

Dariush Norouzian

Nano-Biotechnology Department, Pasteur Institute of Iran, Tehran, Iran; E-mail: dnsa@pasteur.ac.ir

Malihe Keramati

Nano-Biotechnology Department, Pasteur Institute of Iran, Tehran, Iran; Tel./Fax.: (+98-21) 64112171;

E-mail: keramatim@Pasteur.ac.ir, keramati.malihe@gmail.com

\section{INTRODUCTION}

$\mathrm{P}$ rotein purification is the main step of downstream processing of recombinant protein production that might impose a load of more than half of the total process $\operatorname{cost}^{[1]}$. Therefore, development of rapid and efficient methods for purification of target proteins from cell extracts remains as an important issue. Currently, affinity chromatography based on fusion affinity tag, which is co-expressed with the target protein, is one of the welldeveloped techniques for protein separation and purification. In affinity-based purification method, a variety of fusion affinity tags, such as chitin binding

List of Abbreviations:

EGFP, enhanced green fluorescent protein; His-tag, polyhistidine-tag; MNP, magnetic nanoparticle; Ni-NTA, nickel-nitrilotriacetic acid; SEM, scanning electron microscopy; SK, streptokinase; TEOS, tetraethyl orthosilicate; VSM, vibrating sample magnetometer; XRD, X-ray powder diffraction 
domain, maltose binding protein, FLAG-tag, S-tag, and His-tag and their immobilized ligands, have been developed $^{[2,3]}$. In spite of the simplicity of His-tagged protein purification on column chromatography, it bears some limitations, including pretreatment steps to wipe out the cell debris, time-consuming process, and difficult manipulations ${ }^{[2,4]}$. Recently, new separation methods have been developed for purification of Histagged protein based on MNPs ${ }^{[5-8]}$. MNPs are biocompatible nanostructures with high surface area to volume ratio and represent rapid and efficient protein separation traits ${ }^{[5,8,9]}$. Several ionic moieties and groups of compounds, including $\mathrm{Fe}_{3} \mathrm{O}_{4} / \mathrm{IDA}_{-} \mathrm{Cu}^{+2[10]}$, $\mathrm{Fe}_{3} \mathrm{O}_{4} / \mathrm{SiO}_{2}$-GPTMS-Asp-Co ${ }^{[11]}, \quad \mathrm{Fe}_{3} \mathrm{O}_{4} / \mathrm{Au}-\mathrm{ANTA}-$ $\mathrm{Co}^{2+[12]}, \quad \mathrm{Fe}_{3} \mathrm{O}_{4} @ \mathrm{NiSiO}_{3}{ }^{[6]}$, and $\mathrm{Fe}_{3} \mathrm{O}_{4} @ \mathrm{Ni}_{\mathrm{x}} \mathrm{SiO}_{\mathrm{y}}{ }^{[13]}$ ) have been coated on the surface of the MNPs and functionalized them for selective protein separation. Chemical stability, biocompatibility, low cost, and the simple synthesis process for silicate and $\mathrm{Ni}$ surface coating of these MNPs have frequently been reported $^{[6,8,13,14]}$.

Although the efficacy of MNPs with silicate shell and $\mathrm{Ni}$ coat have been shown for the purification of His-tagged protein models expressed in soluble forms under native conditions, their efficiency in purification of those models in inclusion bodies, under denaturing conditions, remains undetermined ${ }^{[11,12]}$. It should be considered that the expression of recombinant proteins in the form of inclusion bodies will increase productivity and facilitate the purification process ${ }^{[15,16]}$. In the present study, two different kinds of MNPs, including $\mathrm{Fe}_{3} \mathrm{O}_{4} @ \mathrm{NiSiO}_{3}$ and $\mathrm{Fe}_{3} \mathrm{O}_{4} @ \mathrm{Ni}_{\mathrm{x}} \mathrm{SiO}_{\mathrm{y}}$, were synthesized, and the capability for His-tagged protein purification in both inclusion bodies (under denaturing conditions) and soluble forms (under native conditions) were assessed. The protein models of EGFP in soluble form and SK as an inclusion body form were used.

\section{MATERIALS AND METHODS}

All chemicals used were of analytical grade. 1Octadecene, $\mathrm{NH}_{3} \cdot \mathrm{H}_{2} \mathrm{O}$ (25\%-28\%), TEOS (98\%), $\mathrm{NaOH}, \mathrm{FeCl}_{3} \cdot 6 \mathrm{H}_{2} \mathrm{O}, \mathrm{NiCl}_{2} \cdot 6 \mathrm{H}_{2} \mathrm{O}(98 \%)$, oleic acid, ammonium chloride, and cetyltrimethyl ammonium bromide were obtained from Sigma-Aldrich, USA. Polyethylene glycol 1000 and $\mathrm{HCl}$ were purchased from Merck (Germany).

\section{Synthesis of $\mathrm{Fe}_{3} \mathrm{O}_{4}$ nanoparticles}

First, $2.8 \mathrm{~g}$ of $\mathrm{FeCl}_{3} \cdot 6 \mathrm{H}_{2} \mathrm{O}$ was dissolved in $30 \mathrm{ml}$ of water, and then a mixture solution (ethanol, $40 \mathrm{ml}$; hexane, $70 \mathrm{ml}$; oleic acid, $9.5 \mathrm{ml}$ ) was added and stirred for $40 \mathrm{~min}$. Next, $0.24 \mathrm{~g}$ of $\mathrm{NaOH}$ was added to the mixture and stirred for $40 \mathrm{~min}$; the resultant mixture was kept at $70{ }^{\circ} \mathrm{C}$ for $4 \mathrm{~h}$. Following the completion of the reaction, the organic layer carrying $\mathrm{Fe}$ (oleate) $)_{3}$ complex was collected and washed with water and dried at $85{ }^{\circ} \mathrm{C}$ overnight. The resultant $\mathrm{Fe}(\text { oleate })_{3}$ was dispersed in oleic acid $(9.6 \mathrm{ml})$ and 1Octadecene $(62.5 \mathrm{ml})$ solution at room temperature and degassed by purging with $\mathrm{N}_{2}$ for $1 \mathrm{~h}$. Subsequently, the mixture was heated to $280{ }^{\circ} \mathrm{C}$ gradually with a rate of 5 ${ }^{\circ} \mathrm{C}$ min- ${ }^{1}$ under $\mathrm{N}_{2}$ flow, then remained at $320{ }^{\circ} \mathrm{C}$ for 1 h. The resulting solution was cooled to room temperature and precipitated by adding $500 \mathrm{ml}$ of acetone and centrifuged at $22,000 \times \mathrm{g}$ for $20 \mathrm{~min}$. Eventually, the precipitated $\mathrm{Fe}_{3} \mathrm{O}_{4}$ nanoparticles were dispersed in chloroform.

\section{Synthesis of $\mathrm{Fe}_{3} \mathrm{O}_{4} @ \mathrm{SiO}_{2}$}

A volume of $0.5 \mathrm{ml}$ of synthesized $\mathrm{Fe}_{3} \mathrm{O}_{4}$ nanoparticles (40 $\mathrm{mg} / \mathrm{ml}$ in chloroform) was added to a 5-ml cetyltrimethyl ammonium bromide solution (55 $\mathrm{mM}$ ) and stirred vigorously for $45 \mathrm{~min}$. Then the solution was warmed up to $65{ }^{\circ} \mathrm{C}$ and kept at $37{ }^{\circ} \mathrm{C}$ for $1 \mathrm{~h}$ to evaporate chloroform. The obtained solution was added to a mixture $(45 \mathrm{ml}$ of water and $0.3 \mathrm{ml}$ of $\mathrm{NaOH} 0.2 \mathrm{M}$ ) and heated up to $75^{\circ} \mathrm{C}$. After $5 \mathrm{~min}, 0.6$ $\mathrm{ml}$ of TEOSwas added, and stirred for $5 \mathrm{~h}$. Finally, the synthesized $\mathrm{Fe}_{3} \mathrm{O}_{4} @ \mathrm{SiO}_{2}$ nanoparticles were dispersed in $20 \mathrm{ml}$ of ethanol.

Synthesis of $\mathrm{Fe}_{3} \mathrm{O}_{4} @ \mathrm{NiSiO}_{3}$ nano-magnetic particles

$\mathrm{Fe}_{3} \mathrm{O}_{4} @ \mathrm{NiSiO}_{3}$ was synthesized based on the Wang's method ${ }^{[6]}$. First, a magnetic core $\left(\mathrm{Fe}_{3} \mathrm{O}_{4}\right)$ was synthesized as described, and then a $\mathrm{SiO}_{2}$ shell was coated on the $\mathrm{Fe}_{3} \mathrm{O}_{4}$ core by Sol-gel procedure (Fig. 1). The synthesized $\mathrm{Fe}_{3} \mathrm{O}_{4} @ \mathrm{SiO}_{2}$ solution was sonicated for $45 \mathrm{~min}$, and mixed with a solution containing $\mathrm{NiCl}_{2} \cdot 6 \mathrm{H}_{2} \mathrm{O}(133.3 \mathrm{mg}), \mathrm{NH}_{4} \mathrm{Cl}(276.5 \mathrm{mg})$ deionized water $(10 \mathrm{ml})$, ethanol $(10 \mathrm{ml})$, and ammonia solution ( $1 \mathrm{ml}, 28 \%)$. The mixture solution was transferred into a Teflon-lined stainless-steel autoclave $(50 \mathrm{ml})$ and sealed to heat at $170{ }^{\circ} \mathrm{C}$ for $10 \mathrm{~h}$. Finally, the resulting precipitate was collected by centrifugation $(22,000 \times \mathrm{g}$, $20 \mathrm{~min}$ ) then washed with deionized water and ethanol and dried at $42{ }^{\circ} \mathrm{C}$ overnight.

\section{Synthesis of $\mathrm{Fe}_{3} \mathrm{O}_{4} @ \mathrm{Ni}_{\mathrm{x}} \mathrm{SiO}_{\mathrm{y}}$ nano-magnetic particles}

$\mathrm{Fe}_{3} \mathrm{O}_{4} @ \mathrm{Ni}_{\mathrm{x}} \mathrm{SiO}_{\mathrm{y}}$ was synthesized as per Wu's method ${ }^{[13]}$. Synthesized $\mathrm{Fe}_{3} \mathrm{O}_{4}(0.20 \mathrm{~g})$ particles were dispersed in $70 \mathrm{ml}$ of a solution of ethanol-waterammonia (50:20:1) and stirred vigorously for $1 \mathrm{~h}$. Following that, a mixture solution containing TEOS $(2 \mathrm{ml})$ and ethanol $(30 \mathrm{ml})$ was added gradually by dropping into the above solution. Next, the mixture was heated up to $50{ }^{\circ} \mathrm{C}$ for $6 \mathrm{~h}$ to achieve $\mathrm{Fe}_{3} \mathrm{O}_{4} @ \mathrm{SiO}_{2}$, 


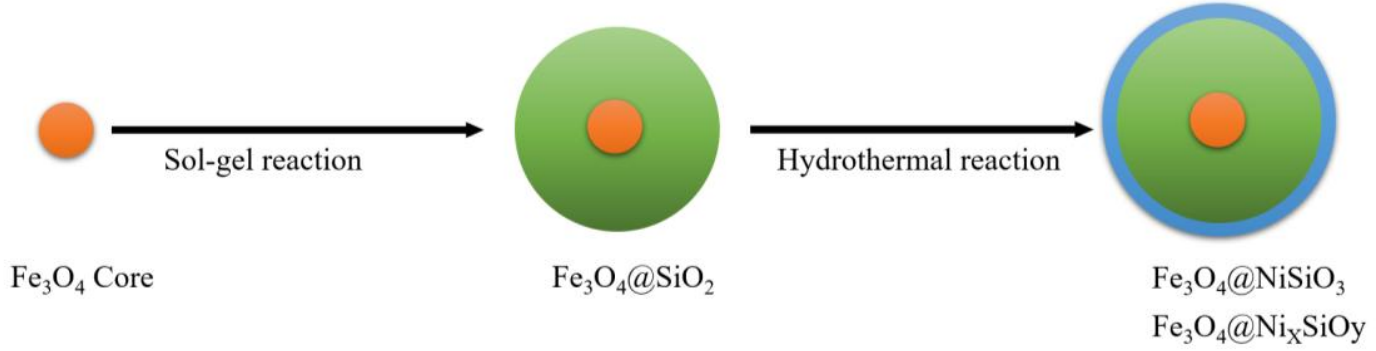

Fig. 1. Schematic representation of MNPs synthesis steps.

and $0.1 \mathrm{~g}$ of obtained $\mathrm{Fe}_{3} \mathrm{O}_{4} @ \mathrm{SiO}_{2}$ was added to $10 \mathrm{ml}$ of $\mathrm{Ni}^{+2}$ solution containing $\mathrm{NiCl}_{2} 6 \mathrm{H}_{2} \mathrm{O}(2 \mathrm{mmol})$ and $\mathrm{NH}_{3} \mathrm{H}_{2} \mathrm{O}(2.5 \mathrm{ml})$. Subsequently, the mixed solution was transferred to a Teflon-lined stainless steel autoclave and heated at $110{ }^{\circ} \mathrm{C}$ for $12 \mathrm{~h}^{[17]}$. After completing the reaction, the $\mathrm{Fe}_{3} \mathrm{O}_{4} @ \mathrm{Ni}_{\mathrm{x}} \mathrm{SiO}_{\mathrm{y}} \mathrm{MNPs}$ were collected by a neodymium magnet.

\section{Characterizations of the MNPs}

The structural properties of the NMPs analyzed by XRD with a X'Pert-PRO advanced diffractometer using $\mathrm{Cu}(\mathrm{K} \alpha)$ radiation (wavelength: $1.5406 \AA$ ) were operated at $40 \mathrm{kV}$ and $40 \mathrm{MA}$ at room temperature with $2 \theta$ intervals. The morphological characteristics and shape of $\mathrm{Fe}_{3} \mathrm{O}_{4} @ \mathrm{SiO}_{2}$ and $\mathrm{Fe}_{3} \mathrm{O}_{4} @ \mathrm{Ni}_{\mathrm{x}} \mathrm{SiO}_{\mathrm{y}} \mathrm{MNPs}$ were identified by SEM using a Philips XL30 ESEM microscope at an accelerating voltage of $5 \mathrm{kV}$. The magnetic features of the MNPs were identified through VSM (Meghnatis Kavir Kashan Co., Kashan, Iran) at room temperature.

\section{Plasmid construction}

All of the cloning steps were performed in Top10 E. coli (Invitrogen ${ }^{\mathrm{TM}}$, USA) using heat shock method based on the standard protocols ${ }^{[18]}$. In order to clone and express recombinant SK-His, the SK gene fragment was amplified by specific primers containing the NdeI and XhoI restriction sites (primers 1 and 2, Table 1) using genomic DNA of Streptococcus equisimilis ATCC 9542, as a template. The PCR product was digested by $\mathrm{NdeI}$ and XhoI enzymes and ligated into pET28a (+) plasmid. For EGFP-His cloning, specific primers containing NdeI and XhoI restrictions sites (primers 3 and 4, Table 1) were used to amplify EGFP gene using pcDNA3-EGFP, as a template. After digestion by the mentioned enzymes, the amplified EGFP was cloned into the pET28a (+) plasmid. Both constructs were confirmed by restriction enzyme analysis.

\section{Protein expression}

The confirmed constructs containing EGFP and SK were separately transformed to $E$. coli BL21 (DE3; Invitrogen ${ }^{\mathrm{TM}}$, USA) competent cells using heat shock method according to standard protocols ${ }^{[18]}$. Clone selection was performed on Luria-Bertani agar plate containing $50 \mathrm{mg} / \mathrm{ml}$ of kanamycin after 18-h incubation at $37{ }^{\circ} \mathrm{C}$. Expression of SK-His and EGFPHis was induced by adding IPTG at the final concentration of $0.8 \mathrm{mM}$ at $16{ }^{\circ} \mathrm{C}$ for $20-22 \mathrm{~h}$. Cells were harvested at $15,000 \times \mathrm{g}$ at $4{ }^{\circ} \mathrm{C}$ for $20 \mathrm{~min}$ and stored at $-80{ }^{\circ} \mathrm{C}$. The harvested cells were resuspended in a 30-ml lysis buffer (stated separately for EGFP-His and SK-His, and then disrupted by sonication (Q125 sonicator, Misonix, USA) at Amp 50, with a $15 \mathrm{~s}$ pulse, $25 \mathrm{~s}$ pause on ice for 15 pulses. The solubilized proteins were separated by centrifugation $(15,000 \times \mathrm{g}$ for $20 \mathrm{~min}$ ), and the clarified cell lysate was used for further purification steps. Final purified EGFP-His and SK-His concentrations were determined by microBradford assay according to the standard protocols, using bovine serum albumin $(0.5-60 \mu \mathrm{g} / \mathrm{ml})$ as standard $^{[19]}$. SDS- PAGE densitometry analysis was performed by ImageJ software (version 1.51n) for semi-quantitative protein assays.

\section{Purification of EGFP-His and SK-His by MNPs}

SK-His and EGFP-His were purified under denaturing and native conditions, respectively. In brief, the frozen cell pellet from SK-His preparation was

Table 1. Primers sequences for gene construction

\begin{tabular}{cll}
\hline No. & Primer name & Sequence (5'-3') \\
\hline 1 & SK-His F NdeI & ATACATATGATTGCTGGACCTGAGTG \\
2 & SK-His R XhoI & ATATCTCGAGTTTGTCGTTAGGGTTATCAG \\
3 & EGFP-His F NdeI & ATACATATGATGGTGAGCAAGGGCGAGG \\
4 & EGFP-His R XhoI & ATACTCGAGCTTGTACAGCTCGTCCATGC
\end{tabular}

Restriction enzymes sites are underlined. 
resuspended in denaturing binding buffer containing 8 $\mathrm{M}$ of urea, $100 \mathrm{mM}$ of $\mathrm{NaH}_{2} \mathrm{PO}_{4}, 100 \mathrm{mM}$ of Tris-Cl, $\mathrm{pH} 8.0$, and sonicated as described before. The solubilized inclusion bodies were mixed with $20 \mathrm{mg}$ of MNPs and incubated at room temperature for $30 \mathrm{~min}$ with gentle shaking. The MNP-trapped His-tagged SK was collected by the neodymium external magnetic force. After three washes with wash buffer $(8 \mathrm{M}$ of urea, $20 \mathrm{mM}$ of $\mathrm{NaH}_{2} \mathrm{PO}_{4}$, and $500 \mathrm{mM}$ of $\mathrm{NaCl}, \mathrm{pH}$ $6.0)$, the fusion proteins were eluted using an elution buffer (6 $\mathrm{M}$ of urea, $100 \mathrm{mM}$ of $\mathrm{NaH}_{2} \mathrm{PO}_{4}$, and 100 $\mathrm{mM}$ of Tris- $\mathrm{HCl}, \mathrm{pH} 4.5)$, and then the MNPs were collected by the neodymium external magnetic force.

In order to purify the EGFP-His, cell lysate was resuspended in a binding buffer $(10 \mathrm{mM}$ of imidazole, $50 \mathrm{mM}$ of $\mathrm{NaH}_{2} \mathrm{PO}_{4}$, and $0.5 \mathrm{M}$ of $\mathrm{NaCl}, \mathrm{pH} 8.0$ ), mixed with $20 \mathrm{mg}$ of MNPs and incubated at room temperature for $30 \mathrm{~min}$ with gentle shaking. The washing step was performed by $8 \mathrm{ml}$ of wash buffer (40 mM of imidazole, $50 \mathrm{mM}$ of $\mathrm{NaH}_{2} \mathrm{PO}_{4}$, and $0.5 \mathrm{M}$ of $\mathrm{NaCl}, \mathrm{pH} 8$ ). Subsequently, the trapped EGFP-His was collected by an elution buffer $(500 \mu \mathrm{l}: 500 \mathrm{mM}$ of imidazole, $50 \mathrm{mM}$ of $\mathrm{NaH}_{2} \mathrm{PO}_{4}$, and $0.5 \mathrm{M}$ of $\mathrm{NaCl}$, $\mathrm{pH}$ 8) for four times, and finally, the MNPs were collected by the neodymium external magnetic force (Fig. 2).

\section{SDS-PAGE and Western blot analyses}

To evaluate the protein expression and identification of purified proteins, SDS-PAGE was carried out according to the standard protocols and Coomassie blue staining $(\mathrm{G} 250)^{[18]}$. Protein identification was conducted by Western blot analysis; the recombinant proteins were transferred to a nitrocellulose membrane, which was detected by horseradish peroxidaseconjugated anti-6x-His-tag® monoclonal antibody (BioLegend, USA). Protein bands were finally visualized by brief exposure to 3,3'-diaminobenzidine (Qiagen, USA).

\section{RESULTS}

\section{Characterizations of $\mathrm{Fe}_{3} \mathrm{O}_{4} @ \mathrm{NiSiO}_{3}$ and $\mathrm{Fe}_{3} \mathrm{O}_{4} @ \mathrm{Ni}_{\mathbf{x}} \mathrm{SiO}_{\mathrm{y}}$}

\section{XRD results}

Figure 3 shows XRD crystallographic structures of $\mathrm{Fe}_{3} \mathrm{O}_{4} @ \mathrm{NiSiO}_{3}$ and $\mathrm{Fe}_{3} \mathrm{O}_{4} @ \mathrm{Ni}_{\mathrm{x}} \mathrm{SiO}_{\mathrm{y}} \mathrm{MNPs}$. As shown in the Figure, both MNPs represent face-centered cubic structures for the $\mathrm{Fe}_{3} \mathrm{O}_{4}$ in their structures (JCPDS 190629) ${ }^{[20,21]}$. Besides, nickel silicate crystal is present in the $\mathrm{Fe}_{3} \mathrm{O}_{4} @ \mathrm{NiSiO}_{3}$ and $\mathrm{Fe}_{3} \mathrm{O}_{4} @ \mathrm{Ni}_{\mathrm{x}} \mathrm{SiO}_{\mathrm{y}}$ structures considering the diffraction peaks in the pattern for the

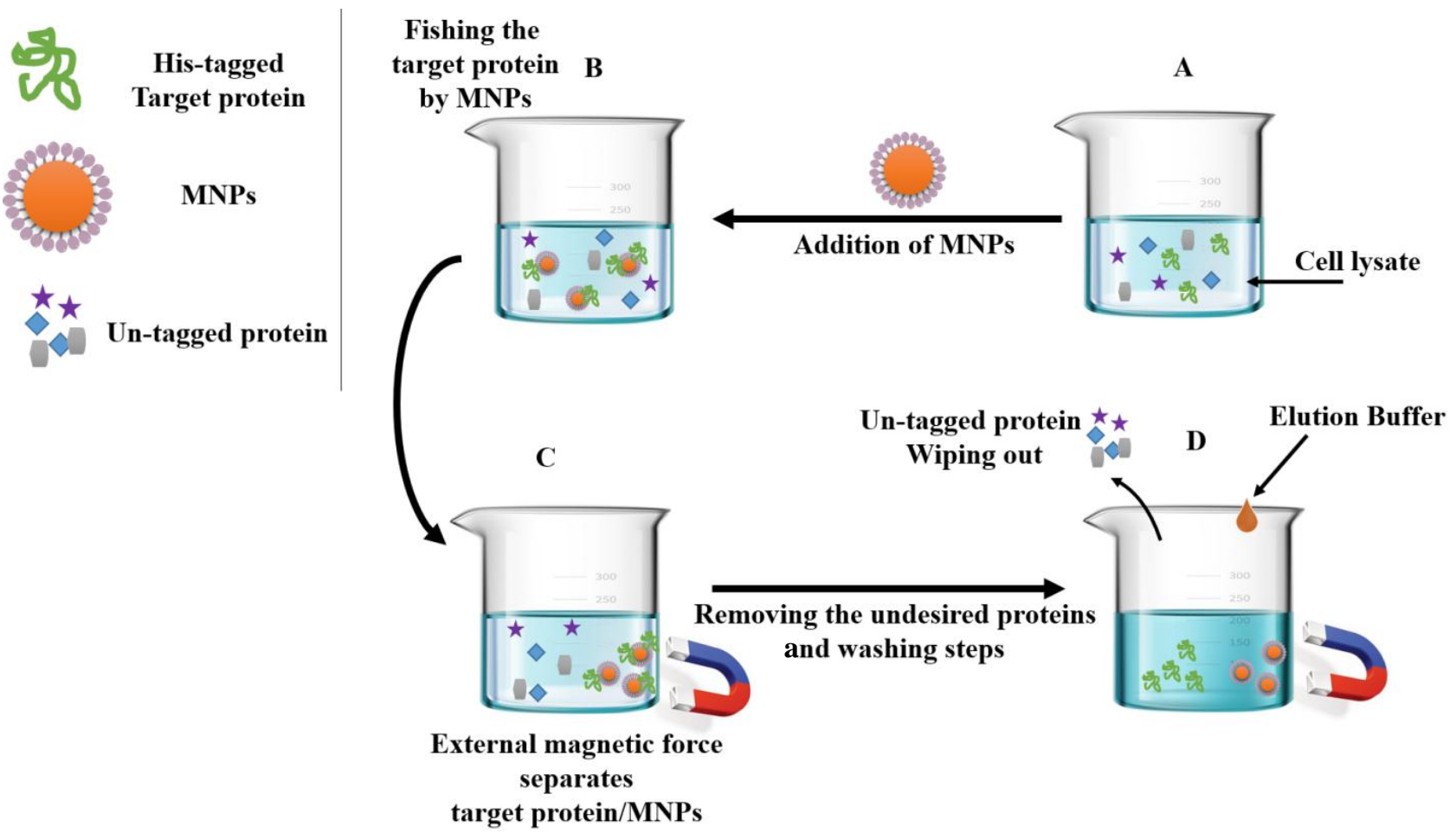

Fig. 2. Schematic representation of protein purification by MNPs. (A) MNPs added to cell lysate containing the His-tagged target protein and untagged protein, (B) MNPs traped the His-tagged target protein, (C) His-tagged target protein/MNPs complex collected by the external magnetic force, and (D) un-tagged proteins removed after wash steps and the His-tagged target protein release by the addition of imidazole. 

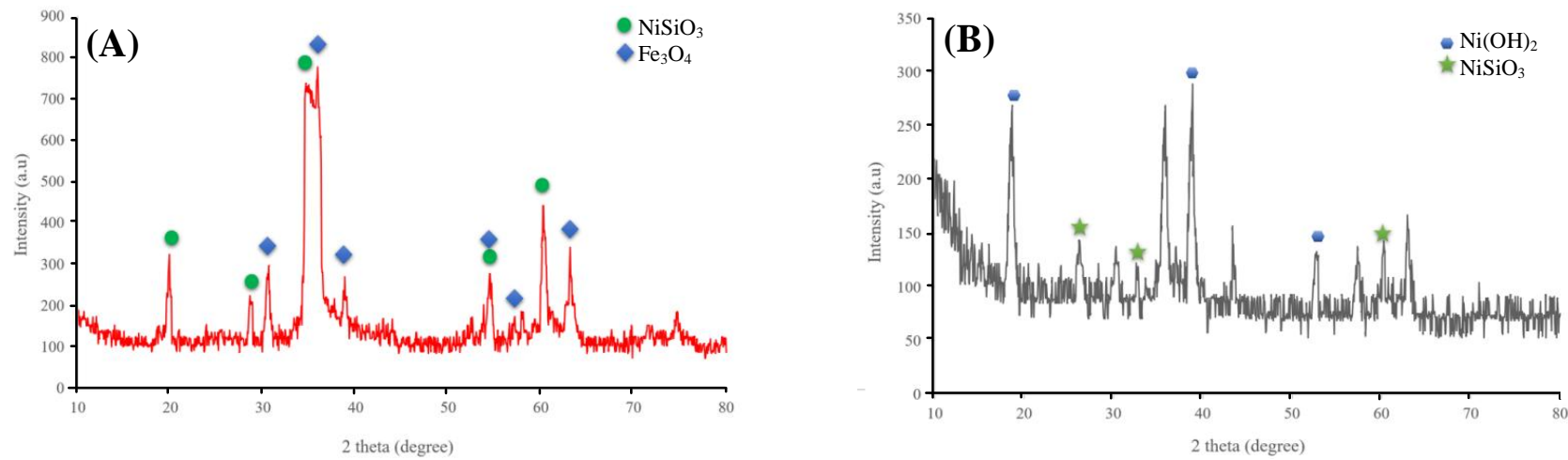

Fig. 3. XRD patterns of nanoparticles. (A) the XRD pattern of $\mathrm{Fe}_{3} \mathrm{O}_{4} @ \mathrm{NiSiO}_{3}$ and $\mathrm{Fe}_{3} \mathrm{O}_{4} @ \mathrm{Ni}_{\mathrm{x}} \mathrm{SiO}_{\mathrm{y}}$ with corresponding picks for $\mathrm{NiSiO}_{3}$ and $\mathrm{Fe}_{3} \mathrm{O}_{4}$ and (B) the XRD pattern of for $\mathrm{Ni}(\mathrm{OH})_{2}$ and $\mathrm{NiSiO}_{3}$, respectively.

MNPs (JCPDS 43-0664) ${ }^{[22]}$. Diffraction peak corresponding to nickel hydroxide is determined in $\mathrm{Fe}_{3} \mathrm{O}_{4} @ \mathrm{Ni}_{\mathrm{x}} \mathrm{SiO}_{\mathrm{y}} \mathrm{XRD}$ pattern (JCPDS 73-1520; Fig. $3 \mathrm{~B})^{[13]}$.

\section{SEM results}

The SEM images in Figure 4 illustrate the spherical shape for both $\mathrm{Fe}_{3} \mathrm{O}_{4} @ \mathrm{NiSiO}_{3}$ and $\mathrm{Fe}_{3} \mathrm{O}_{4} @ \mathrm{Ni}_{\mathrm{x}} \mathrm{SiO}_{\mathrm{y}}$ MNPs with the widely different sizes about $330 \pm 35$ $\mathrm{nm}$ (Fig. 4A) for the former and about $370 \pm 40 \mathrm{~nm}$ (Fig. 4B) for the latter.

\section{Magnetization properties result by VSM}

As shown in Figure 5, the obtained magnetization curve for both $\mathrm{Fe}_{3} \mathrm{O}_{4} @ \mathrm{NiSiO}_{3}$ and $\mathrm{Fe}_{3} \mathrm{O}_{4} @ \mathrm{Ni}_{\mathrm{x}} \mathrm{SiO}_{\mathrm{y}}$

(A)
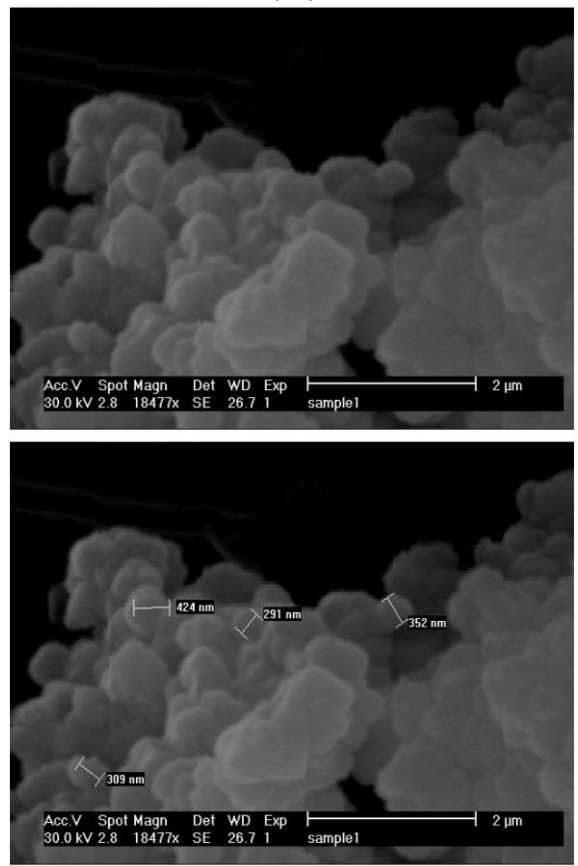

MNPs show superparamagnetic properties, which suggest that magnetic remanence and coercive force are zero. The specific magnetization saturation values were $4.02 \mathrm{emu} / \mathrm{g}$ and $2.91 \mathrm{emu} / \mathrm{g}$ for $\mathrm{Fe}_{3} \mathrm{O}_{4} @ \mathrm{NiSiO}_{3}$ and $\mathrm{Fe}_{3} \mathrm{O}_{4} @ \mathrm{Ni}_{\mathrm{x}} \mathrm{SiO}_{\mathrm{y}}$, respectively, indicating a suitable magnetic property for both MNPs in the presence of an external magnetic force.

\section{His-tagged protein purification by $\mathrm{Fe}_{3} \mathrm{O}_{4} @ \mathrm{NiSiO}_{3}$ and $\mathrm{Fe}_{3} \mathrm{O}_{4} @ \mathrm{Ni}_{\mathrm{x}} \mathrm{SiO}_{\mathrm{y}}$}

As illustrated in Figure 6, both $\mathrm{Fe}_{3} \mathrm{O}_{4} @ \mathrm{NiSiO}_{3}$ and $\mathrm{Fe}_{3} \mathrm{O}_{4} @ \mathrm{Ni}_{\mathrm{x}} \mathrm{SiO}_{\mathrm{y}} \mathrm{MNPs}$ successfully purified EGFPHis, directly from the cell lysate. Binding capacities for both MNPs were measured after the addition of the MNPs to an excessive amount of cell lysate
(B)
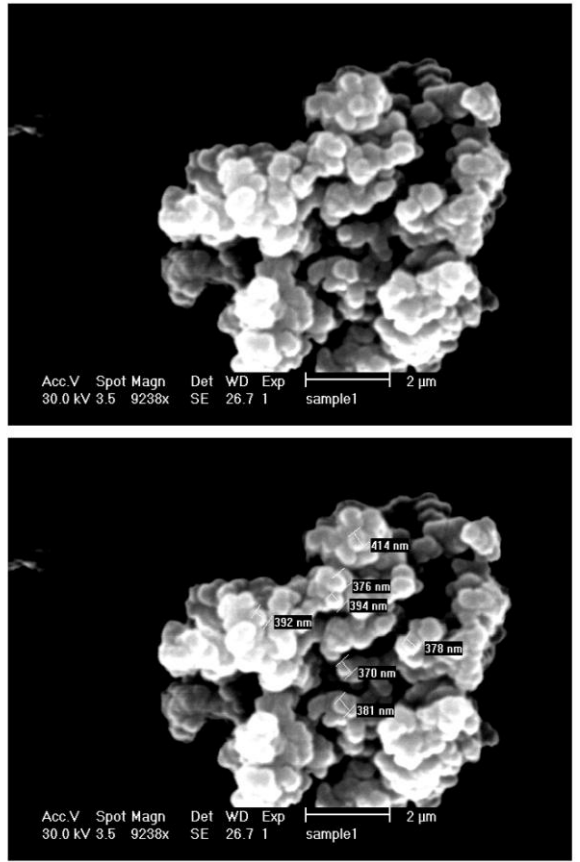

Fig. 4. The SEM image of MNPs with the measured scale from (A) $\mathrm{Fe}_{3} \mathrm{O}_{4} @ \mathrm{NiSiO}_{3}$ and (B) $\mathrm{Fe}_{3} \mathrm{O}_{4} @ \mathrm{Ni}_{\mathrm{x}} \mathrm{SiO}_{\mathrm{y}} \mathrm{MNPs}$. 

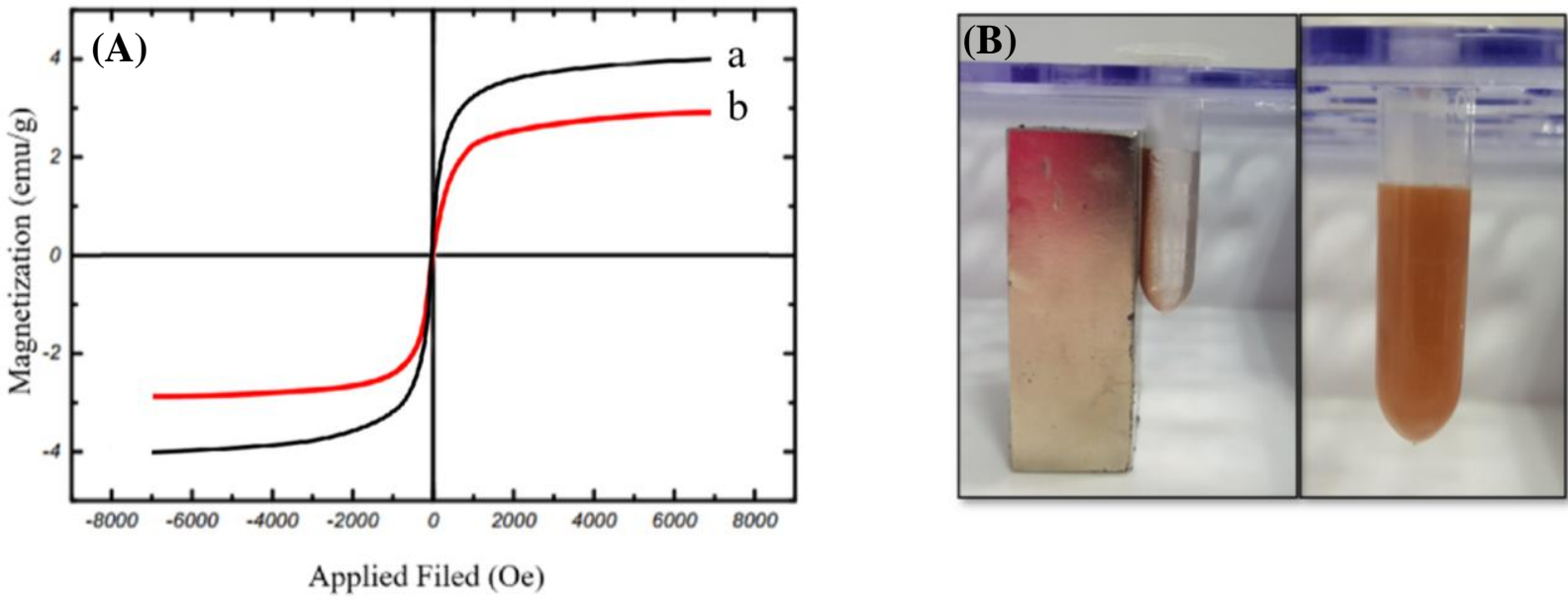

Fig. 5. Magnetic properties of the synthesized MNPs (A) VSM result of magnetic separation and redispersion process of the MNPs in PBS. (A) VSM results for (a) $\mathrm{Fe}_{3} \mathrm{O}_{4} @ \mathrm{NiSiO}_{3}$ and (b) $\mathrm{Fe}_{3} \mathrm{O}_{4} @ \mathrm{Ni}_{\mathrm{x}} \mathrm{SiO}_{\mathrm{y}}$. (B) $\mathrm{Fe}_{3} \mathrm{O}_{4} @ \mathrm{NiSiO}_{3} \mathrm{MNPs}$ in disperse form and in the presence of a magnetic force.

containing EGFP-His. The results indicated that the $\mathrm{Fe}_{3} \mathrm{O}_{4} @ \mathrm{NiSiO}_{3} \mathrm{MNPs}$ were able to capture EGFP-His at $16565 \pm 8 \mu \mathrm{g}$ per $80 \mathrm{mg}$ of MNPs $(207 \mu \mathrm{g} / \mathrm{mg})$. This amount was $15605 \pm 6 \mu \mathrm{g}$ per $80 \mathrm{mg}$ of $\mathrm{Fe}_{3} \mathrm{O}_{4} @ \mathrm{Ni}_{\mathrm{x}} \mathrm{SiO}_{\mathrm{y}} \quad \mathrm{MNPs} \quad(195 \mu \mathrm{g} / \mathrm{mg})$. All measurements were in triplicates (Table 2). Samples from different steps of the purification process (Fig. 2) of EGFP-His were loaded on SDS-PAGE for further analysis and confirmed by Western blot. As shown in
Figure 7 and Figure 9B, a sharp protein band is apparent between $25 \mathrm{kDa}$ and $35 \mathrm{kDa}$ positions of the protein marker, which corresponds to EGFP-His (30 $\mathrm{kDa})$. The purity percentages of both MNPs was calculated by ImageJ software (version $1.51 \mathrm{n}$ ), and the result represented more purity of $\mathrm{Fe}_{3} \mathrm{O}_{4} @ \mathrm{NiSiO}_{3}$ than $\mathrm{Fe}_{3} \mathrm{O}_{4} @ \mathrm{Ni}_{\mathrm{x}} \mathrm{SiO}_{\mathrm{y}}$ (Table 2). Purified SK-His by the two MNPs was loaded on SDS-PAGE for evaluating the quality of purification process. As shown in Figures 8

(A)

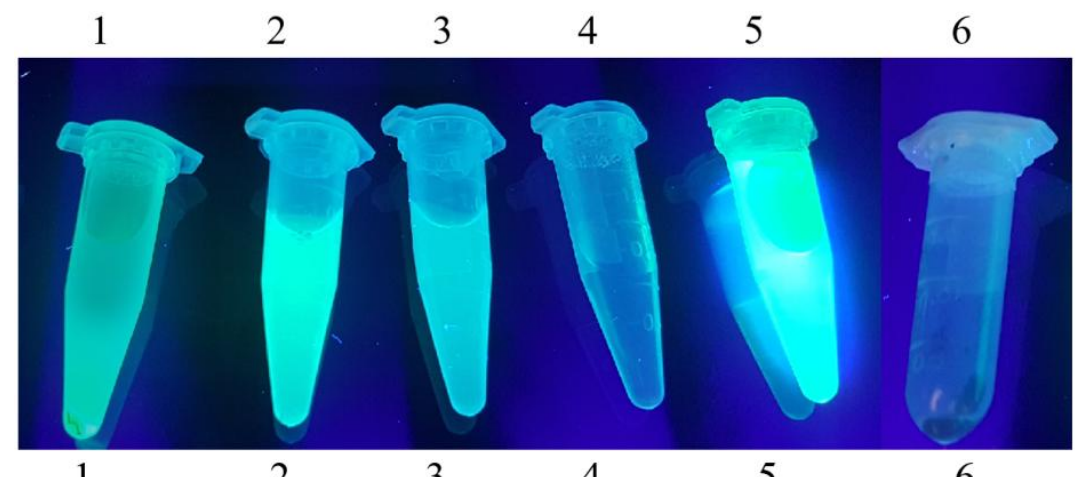

(B)

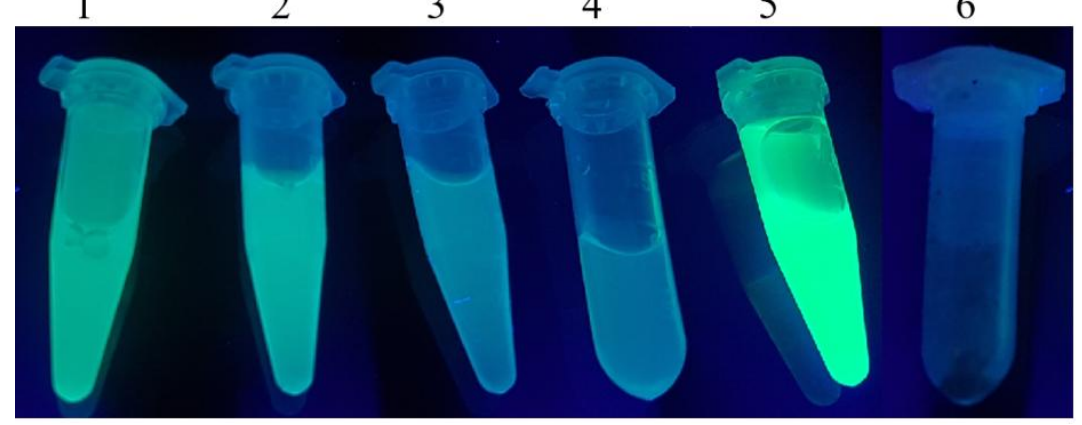

Fig. 6. EGFP-His trapping by MNPs visualized by ultraviolet light (UV $538 \mathrm{~nm}$ ). (A) 1,Un-attached EGFP-His and cell lysate; 2-4, 1st to 3rd wash of the $\mathrm{Fe}_{3} \mathrm{O}_{4} @ \mathrm{NiSiO}_{3} \mathrm{MNPs}$; 5, final elution by imidazole $(300 \mathrm{mM}) ; 6, \mathrm{Fe}_{3} \mathrm{O}_{4} @ \mathrm{NiSiO}_{3} \mathrm{MNPs}$ after the purification process. (B) 1, Un-attached EGFP-His and cell lysate; 2-4, 1st to 3rd wash of the $\mathrm{Fe}_{3} \mathrm{O}_{4} @ \mathrm{Ni}_{\mathrm{x}} \mathrm{SiO}_{\mathrm{y}} \mathrm{MNPs} ; 5$, final elution by imidazole (300 mM); 6, $\mathrm{Fe}_{3} \mathrm{O}_{4} @ \mathrm{Ni}_{\mathrm{x}} \mathrm{SiO}_{\mathrm{y}} \mathrm{MNPs}$ after the purification process. 
Table 2. Protein purification and quantification via MNPs

\begin{tabular}{cccccc}
\hline Protein & $\begin{array}{c}\text { Purification } \\
\text { conditions }\end{array}$ & $\mathbf{M N P}$ & $\begin{array}{c}\text { Yield } \\
(\boldsymbol{\mu g} / \mathbf{m g})\end{array}$ & $\begin{array}{c}\text { Standard } \\
\text { deviation }(\boldsymbol{\mu g} / \mathbf{m g})\end{array}$ & $\begin{array}{c}\text { Purity } \\
(\boldsymbol{\%})^{\mathbf{b}}\end{array}$ \\
\hline \multirow{2}{*}{ SK-His } & Denature & $\mathrm{Fe}_{3} \mathrm{O}_{4} @ \mathrm{NiSiO}_{3}$ & 192 & \pm 4.4 & $\sim 81$ \\
& & $\mathrm{Fe}_{3} \mathrm{O}_{4} @ \mathrm{Ni}_{\mathrm{x}} \mathrm{SiO}_{\mathrm{y}}$ & 188 & \pm 3.4 & $\sim 80$ \\
\multirow{2}{*}{ EGFP-His } & \multirow{2}{*}{ Native } & $\mathrm{Fe}_{3} \mathrm{O}_{4} @ \mathrm{NiSiO}_{3}$ & 207 & \pm 3.9 & $\sim 73$ \\
& & $\mathrm{Fe}_{3} \mathrm{O}_{4} @ \mathrm{Ni}_{\mathrm{x}} \mathrm{SiO}_{\mathrm{y}}$ & 195 & \pm 4.1 & $\sim 71$ \\
\hline
\end{tabular}

All values and errors were represented as mean and standard deviations, respectively, from three independent purification experiments. ${ }^{\mathrm{a}}$ Purification yields were determined using $80 \mathrm{mg}$ of MNPs; ${ }^{\mathrm{b}} \mathrm{Purity}$ percentage was estimated using densitometry analysis on SDS-PAGE.

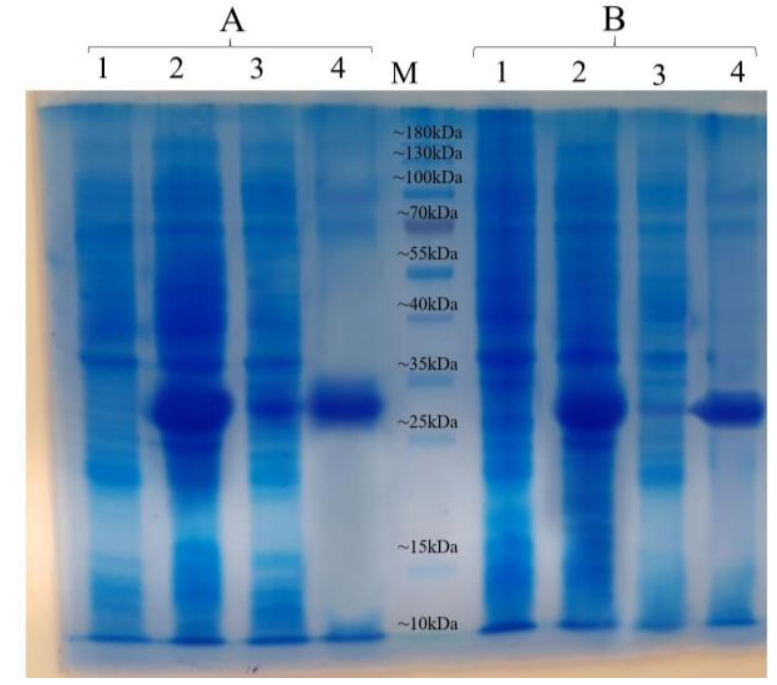

Fig. 7. SDS-PAGE result for EGFP-His purification by the MNPs under native conditions. EGFP-His purification via (A) $\mathrm{Fe}_{3} \mathrm{O}_{4} @ \mathrm{NiSiO}_{3}$ and (B) $\mathrm{Fe}_{3} \mathrm{O}_{4} @ \mathrm{NiSiO}_{3}$ MNPs: lanes 1, uninduced cell lysate; lanes 2, induced cell lysate after $22 \mathrm{~h}$; lanes 3 , cell lysate after purification by $\mathrm{Fe}_{3} \mathrm{O}_{4} @ \mathrm{NiSiO}_{3}$ and $\mathrm{Fe}_{3} \mathrm{O}_{4} @ \mathrm{Ni}_{\mathrm{x}} \mathrm{SiO}_{\mathrm{y}} \mathrm{MNPs} ;$ lane 4, purified EGFP-His by $\mathrm{Fe}_{3} \mathrm{O}_{4} @ \mathrm{NiSiO}_{3}$ and $\mathrm{Fe}_{3} \mathrm{O}_{4} @ \mathrm{Ni}_{\mathrm{x}} \mathrm{SiO}_{\mathrm{y}} \mathrm{MNPs}$ in final elution via imidazole; $\mathrm{M}$, protein marker

and 9A, a sharp and specific protein band is visible around $47 \mathrm{kDa}$. The SK-His purity percentages of both MNPs calculated by ImageJ software revealed almost the same purity percentage for both synthesized MNPs (Table 2). As shown in Figure 9, Western blotting analyses of the purified EGFP-His and SK-His confirmed the validity of the purified protein by both $\mathrm{Fe}_{3} \mathrm{O}_{4} @ \mathrm{NiSiO}_{3}$ and $\mathrm{Fe}_{3} \mathrm{O}_{4} @ \mathrm{Ni}_{\mathrm{x}} \mathrm{SiO}_{\mathrm{y}}$ MNPs.

\section{DISCUSSION}

In the current study, we have synthesized two MNPs with the magnetic core of $\mathrm{Fe}_{3} \mathrm{O}_{4}, \mathrm{SiO}_{2}$ shell, and immobilized $\mathrm{Ni}^{2+}$ on the surface to examine the capability of the MNPs for His-tagged protein purification from inclusion bodies. The inclusion bodies form of SK-His was purified successfully beside the soluble EGFP-His as the model proteins.
Purification of EGFP-His and SK-His under native and denature conditions demonstrated an average purity of $72 \%$ and $80 \%$, respectively

Evaluation by XRD (Fig. 3), SEM (Fig. 4), and VSM (Fig. 5) of both $\mathrm{Fe}_{3} \mathrm{O}_{4} @ \mathrm{NiSiO}_{3}$ and $\mathrm{Fe}_{3} \mathrm{O}_{4} @ \mathrm{Ni}_{\mathrm{x}} \mathrm{SiO}_{\mathrm{y}}$ MNPs confirmed their structure, morphology, size, and magnetization properties the same as the previous reports ${ }^{[6,13]}$. The measured $\mathrm{Fe}_{3} \mathrm{O}_{4} @ \mathrm{NiSiO}_{3}$ MNPs binding capacity for EGFP-His (30 kDa) was 207 $\mu \mathrm{g} / \mathrm{mg}$, which was comparable with Wang et al ${ }^{[6]}$ result (220 $\mu \mathrm{g} / \mathrm{mg})$. However, $\mathrm{Fe}_{3} \mathrm{O}_{4} @ \mathrm{Ni}_{\mathrm{x}} \mathrm{SiO}_{\mathrm{y}}$ represented $195 \mu \mathrm{g} / \mathrm{mg}$ binding capacity, which was similar to the result obtained by Wu and co-workers ${ }^{[13]}(193 \mu \mathrm{g} / \mathrm{mg})$. More than $70 \%$ purity for both MNPs was obtained (Table 2), which is a suitable purity rate under the native conditions. However, buffer optimization and the increase of the total amount of immobilized $\mathrm{Ni}^{2+}$ on the MNPs surface could lead to more purity percentages.

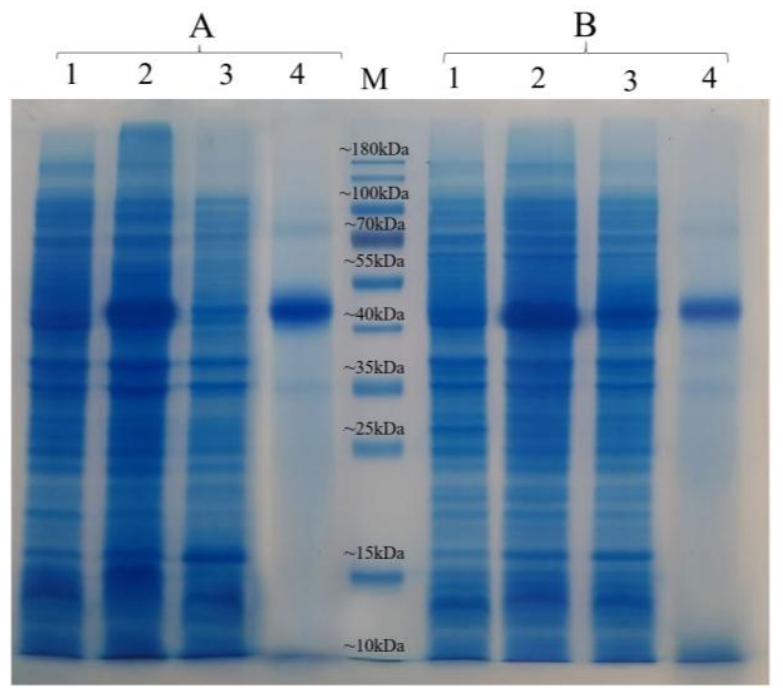

Fig. 8. SDS-PAGE result for SK-His purification by the MNPs under the denature conditions. SK-His purification via (A) $\mathrm{Fe}_{3} \mathrm{O}_{4} @ \mathrm{NiSiO}_{3}$ and (B) $\mathrm{Fe}_{3} \mathrm{O}_{4} @ \mathrm{Ni}_{\mathrm{x}} \mathrm{SiO}_{\mathrm{y}}$ MNPs: lanes 1, uninduced cell lysate; lanes 2 , induced cell lysate after $22 \mathrm{~h}$; lanes 3 , cell lysate after purification by $\mathrm{Fe}_{3} \mathrm{O}_{4} @ \mathrm{NiSiO}_{3}$ and $\mathrm{Fe}_{3} \mathrm{O}_{4} @ \mathrm{Ni}_{\mathrm{x}} \mathrm{SiO}_{\mathrm{y}} \mathrm{MNPs}$; lanes 4, purified SK-His by $\mathrm{Fe}_{3} \mathrm{O}_{4} @ \mathrm{NiSiO}_{3}$ and $\mathrm{Fe}_{3} \mathrm{O}_{4} @ \mathrm{Ni}_{\mathrm{x}} \mathrm{SiO}_{\mathrm{y}}$ MNPs in elution buffer; $\mathrm{M}$, protein marker 


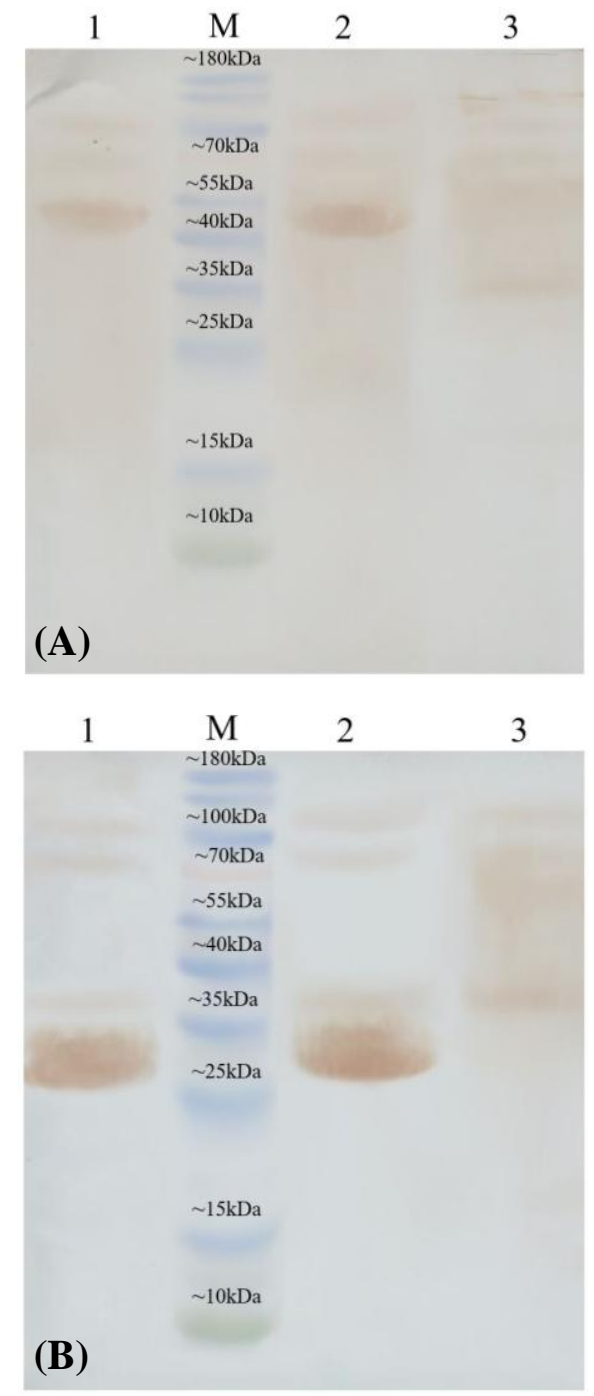

Fig. 9. Western Blot result for SK-His and EGFP-His purified by the synthesized MNPs. Western blot result for purified (A) SK-His and (B) EGFP-His under the denature conditions: lanes 1, purified SK-His and EGFP_His by $\mathrm{Fe}_{3} \mathrm{O}_{4} @ \mathrm{NiSiO}_{3}$ MNPs; lanes 2, purified SK-His by $\mathrm{Fe}_{3} \mathrm{O}_{4} @ \mathrm{Ni}_{\mathrm{x}} \mathrm{SiO}_{\mathrm{y}} \mathrm{MNPs}$; lane 3, uninduce cell lysate. $\mathrm{M}$, protein marker

Inclusion body expression is a well-known strategy for SK production ${ }^{[15]}$; therefore, it was used as a model protein for inclusion body purification under the denaturing conditions. $\mathrm{Fe}_{3} \mathrm{O}_{4} @ \mathrm{NiSiO}_{3}$ and $\mathrm{Fe}_{3} \mathrm{O}_{4} @ \mathrm{Ni}_{\mathrm{x}} \mathrm{SiO}_{\mathrm{y}} \mathrm{MNPs}$ were represented purification capability under the denaturing conditions with the yield of $192 \mu \mathrm{g} / \mathrm{mg}$ and $188 \mu \mathrm{g} / \mathrm{mg}$, respectively (Table 2). Despite the fewer yields as compared to EGFP-His, the average purity percentage obtained by both MNPs under the denaturing conditions was higher than that of EGFP-His (80\% vs. 72\%). Harsh denaturing conditions unfolds the proteins structure; consequently, unspecific attachment to the MNPs decreases, and fusion His tag can easily binds to immobilized $\mathrm{Ni}$ on the surface of
MNPs. MNPs $\mathrm{Fe}_{3} \mathrm{O}_{4} / \mathrm{PMG} / \mathrm{IDA}-\mathrm{Ni}^{2+}(103 \mu \mathrm{g} / \mathrm{mg})^{[23]}$, $\mathrm{Fe}_{3} \mathrm{O}_{4} \mathrm{Au}-\mathrm{ANTA}-\mathrm{Co}^{2+}(74 \mu \mathrm{g} / \mathrm{mg})^{[12]}$, and chitosan/ $\mathrm{Fe}_{3} \mathrm{O}_{4} \quad(62.8 \mu \mathrm{g} / \mathrm{mg})^{[24]}$ with different kinds of conjugated groups and different binding capacities have been reported. However, the binding capacities of these MNPs may be affected under harsh denaturing conditions due to the complexes in their structures.

In conclusion, MNPs with a magnetic core of $\mathrm{Fe}_{3} \mathrm{O}_{4}$, $\mathrm{SiO}_{2}$ shell, and immobilized $\mathrm{Ni}^{2+}$ on the surface (Fig. 1) can purify His-tagged protein from inclusion bodies approximately up to $80 \%$. The binding capacities for both synthesized $\mathrm{Fe}_{3} \mathrm{O}_{4} @ \mathrm{NiSiO}_{3}$ and $\mathrm{Fe}_{3} \mathrm{O}_{4} @ \mathrm{Ni}_{\mathrm{x}} \mathrm{SiO}_{\mathrm{y}}$ MNPs were suitable and comparable with their performance under the native conditions. Low-cost production along with high binding capacity and purity percentage makes $\mathrm{Fe}_{3} \mathrm{O}_{4} @ \mathrm{NiSiO}_{3}$ and $\mathrm{Fe}_{3} \mathrm{O}_{4} @ \mathrm{Ni}_{\mathrm{x}} \mathrm{SiO}_{\mathrm{y}}$ MNPs attractive choices for His-tagged protein purification from inclusion bodies.

\section{ACKNOWLEDGMENTS}

This work was financially supported by the Pasteur Institute of Iran and performed in partial fulfillment of Ph.D. thesis of M. Seyedinkhorasani.

CONFLICT OF INTEREST. None declared.

\section{REFERENCES}

1. Roque AC, Lowe CR, Taipa MA. Antibodies and genetically engineered related molecules: production and purification. Biotechnology progress 2004; 20(3): 639-654.

2. Arnau J, Lauritzen C, Petersen GE, Pedersen L. Current strategies for the use of affinity tags and tag removal for the purification of recombinant proteins. Protein expression and purification 2006; 48(1): 1-13.

3. Lichty JJ, Malecki JL, Agnew HD, Michelson-Horowitz DJ, Tan S. Comparison of affinity tags for protein purification. Protein expression and purification 2005; 41(1): 98-105.

4. Vassylyeva MN, Klyuyev S, Vassylyev AD, Wesson H, Zhang Z, Renfrow MB, Wang H, Higgins NP, Chow LT, Vassylyev DG., Efficient, ultra-high-affinity chromatography in a one-step purification of complex proteins. Proceedings of the national academy of sciences 2017; 114(26): E5138-E5147.

5. Jiang, M, Zhang L, Wang F, Zhang J, Liu G, Gao B, Wei D. Novel application of magnetic protein: convenient one-step purification and immobilization of proteins. Scientific reports 2017; 7: Article number 13329.

6. Wang Y, Wang G, Xiao Y, Yang Y, Tang R. Yolk-shell nanostructured $\mathrm{Fe}_{3} \mathrm{O}_{4} @ \mathrm{NiSiO} 3$ for selective affinity and magnetic separation of His-tagged proteins. ACS 
applied materials and interfaces 2014; 6(21): $19092-$ 19099.

7. Liu Z, Li M, Pu F, Ren J, Yang X, Qu X. Hierarchical magnetic core-shell nanoarchitectures: non-linker reagent synthetic route and applications in a biomolecule separation system. Journal of materials chemistry 2012; 22(7): 2935-2942.

8. Xu F, Geiger JH, Baker GL, Bruening ML. Polymer brush-modified magnetic nanoparticles for His-tagged protein purification. Langmuir 2011; 27(6): 3106-3112.

9. Xu J, Sun J, Wang Y, Sheng J, Wang F, Sun M. Application of iron magnetic nanoparticles in protein immobilization. Molecules 2014; 19(8): 11465-11486.

10. Meyer A, Hansen DB, Gomes CS, Hobley TJ, Thomas OR, Franzreb M. Demonstration of a strategy for product purification by high- gradient magnetic fishing: recovery of superoxide dismutase from unconditioned whey. Biotechnology progress 2005; 21(1): 244-254.

11. Feng G, Hu D, Yang L, Cui Y, Cui X, Li H. Immobilized-metal affinity chromatography adsorbent with paramagnetism and its application in purification of histidine-tagged proteins. Separation and purification technology 2010; 74(2): 253-260.

12. Zhang L, Zhu X, Jiao D, Sun Y, Sun H. Efficient purification of His-tagged protein by superparamagnetic $\mathrm{Fe}_{3} \mathrm{O}_{4} / \mathrm{Au}-\mathrm{ANTA}-\mathrm{Co} 2+$ nanoparticles. Materials science and engineering C 2013; 33(4): 1989-1992.

13. Wu Y, Chang G, Zhao Y, Zhang Y. Hierarchical $\mathrm{Fe}_{3} \mathrm{O}_{4} @ \mathrm{Ni}_{\mathrm{x}} \mathrm{SiO}_{\mathrm{y}}$ microspheres for affinity separation of His-tagged proteins. Journal of nanoparticle research 2014; 16(4): 2358.

14. Zhang $\mathrm{Y}$, Zhang $\mathrm{M}$, Yang J, Ding L, Zheng J, Xu J, Xiong S. Formation of $\mathrm{Fe}_{3} \mathrm{O}_{4} @ \mathrm{SiO}_{2} @ \mathrm{C} / \mathrm{Ni}$ hybrids with enhanced catalytic activity and histidine-rich protein separation. Nanoscale 2016; 8(35): 15978-15988.

15. Nguyen ST, Quyen DT, Vu HD. Highly effective renaturation of a streptokinase from Streptococcus pyogenes DT7 as inclusion bodies overexpressed in Escherichia coli. Biomed research international 2014; 2014: 324705.
16. Peterson MJ, Snyder WK, Westerman S, McFarland B. Preparative protein production from inclusion bodies and crystallization: a seven-week biochemistry sequence. Journal of chemical education 2011; 88(7): 986-989.

17. Wu Y, Chang G, Zhao Y, Zhang Y. Preparation of hollow nickel silicate nanospheres for separation of Histagged proteins. Dalton transactions 2014; 43(2): 779783.

18. Sambrook JF, Russell DW. Molecular Cloning: A Laboratory Manual. $3^{\text {rd }}$ ed. New York: Cold Spring Harbor Laboratory Press; 2001.

19. Kruger NJ. The Bradford Method for Protein Quantitation. In: Walker JM, editor. The Protein Protocols Handbook. New Jersey: Springer; 2009. p. 1724.

20. Wang Y, Shen Y, Xie A, Li S, Wang X, Cai Y. A simple method to construct bifunctional $\mathrm{Fe}_{3} \mathrm{O}_{4} / \mathrm{Au}$ hybrid nanostructures and tune their optical properties in the near-infrared region. The journal of physical chemistry C 2010; 114(10): 4297-4301.

21. Wang Y, Li S, Xing X, Huang F, Shen Y, Xie A, Wang $\mathrm{X}$, Zhang J. Self- assembled 3D flowerlike hierarchical $\mathrm{Fe}_{3} \mathrm{O}_{4} @ \mathrm{Bi}_{2} \mathrm{O}_{3}$ core-shell architectures and their enhanced photocatalytic activity under visible light. Chemistry 2011; 17(17): 4802-4808.

22. Liu Z, Li M, Yang X, Yin M, Ren J, Qu X. The use of multifunctional magnetic mesoporous core/shell heteronanostructures in a biomolecule separation system. Biomaterials 2011; 32(21): 4683-4690.

23. Zhang Y, Yang Y, Ma W, Guo J, Lin Y, Wang C. Uniform magnetic core/shell microspheres functionalized with $\mathrm{Ni2}+$-iminodiacetic acid for one step purification and immobilization of his-tagged enzymes. ACS applied materials and interfaces 2013; 5(7): 2626-2633.

24. Zhi J, Wang Y, Lu Y, Ma J, Luo GS. In situ preparation of magnetic chitosan/ $/ \mathrm{Fe}_{3} \mathrm{O}_{4}$ composite nanoparticles in tiny pools of water-in-oil microemulsion. Reactive and hunctional polymers 2006; 66(12): 1552-1558. 